\title{
A Confirmatory Structural Equation Model of Achievement Estimated by Dichotomous Attitudes, Interest, and Conceptual Understanding
}

\author{
Minkee Kim \\ Bilkent University, Ankara, TURKEY \\ Jinwoong Song \\ Seoul National University, Seoul, REPUBLIC OF KOREA
}

Received 22 September 2009; accepted 13 May 2010

\begin{abstract}
Many models in science education have tried to clarify the causal relationships of affective variables on student performance, by presenting theoretical models, exploratory SEM (structural equation models), and confirmatory SEM. Based on the literature, the recent AS-TI-CU model scrutinised the most robust stimuli of conceptual understanding (CU): intrinsic attitude towards science (AS) and topic interest (TI). However, the confirmatory model has not been extended to estimate how students achieve in the secondary science or in Korea where student's disengagement in science is prevalent. Sampling $10^{\text {th }}$ - and $11^{\text {th }}$ graders in Korea $(N=219)$, this study thus aims to clarify how the forth factor "school achievement (SA)" interacts in the structural equation modelling. The multiple-group SEM analysis in AMOS7 reveals that student's intrinsic AS stimulates their school achievement in both graders and that their topic interest abnormally discourages school achievement only in the $11^{\text {th }}$-graders. The findings provide explanations for the latent threats of negative attitudes and for the "age 14's dip". Lastly, how to form a theory of persuasion of attitude change is discussed for a further research question.
\end{abstract}

Keywords: Dichotomous Attitudes, Topic Interest, Conceptual Understanding, Achievement, Persuasion of Attitude Change

\section{INTRODUCTION}

Individual students have long been recognised to conceive, understand, and propagate science as public understanding (Ziman, 1968). Student's personal understanding cannot be divorced from their belief and knowledge of science, and their understanding is incomplete and is not often accepted by canonical science. Particularly in science education, there exists a reason of why the incomplete understanding of science from individual students matters: students possess their own attitudes and images towards science as filters

Correspondence to: Minkee Kim; Visiting Assistant Professor, Graduate School of Education, Bilkent University, Ankara 06800,TURKEY

E-mail:physhero@gmail.com when scientific knowledge is instructed by a science teacher (Head, 1985). Accordingly, many studies in science education have examined student's affective variables (attitudes and interest) towards science during the last three decades (Barmby, Kind, \& K. Jones, 2008; Nieswandt, 2005; Schibeci, 1984; Koballa, 1992).

To promote student's performance in science, many national or international researches, Programme for International Student Assessment (PISA) and Trends in International Mathematics and Science Study (TIMSS), have carried out quantitative assessments of science learners in secondary schools. Their findings, by examining student's mastery of science contents, are frequently used for political purposes, rather than for deeper understanding of student's learning. Baker and Jones (2005) warned that performance-centred education would result in the disengagement of science among pupils. For example, in Asian countries where a 


\section{State of the literature}

- Correlational studies have estimated relationships between student affective and cognitive variables by theoretical models, exploratory SEM, and confirmatory SEM.

- The latest SEM suggests discerning student's attitudes towards science into intrinsic and extrinsic attitudes among students in moredeveloped countries.

- However, it has not been studied how dichotomous attitudes towards science relate to student's school achievement.

\section{Contribution of this paper to the literature}

- This paper reveals the effects of student's dichotomous (intrinsic and extrinsic) attitudes towards science on school achievement.

- Intrinsic AS - student's preference on careers in S\&T and school science - robustly influences school achievement mostly by indirect effects.

- The AS-TI-CU-SA model clarifies that negative attitude towards science would decrease number of applicants to careers in S\&T and would discourage students to become talented in school science.

- The model provides information to explain the latent threats of negative attitudes toward science and the "age 14's dip".

competitive culture of education drives students to focus mainly on rote-memorising subject concepts for their higher scores in school tests and for their university entrance examination, science education in their private cram schools (special, additional schoolings) have been determined to aggravate student's emotional detachment from school science (Tsai \& Kuo, 2008). Especially in Korea, parental wish for education is suggested as the most influential factor for the student's high achievement in PISA science (Kim, Lavonen, \& Ogawa, 2009). Since the motivation to learn does not solely arise from the learner's mind, it is worthwhile examining Korean student's attitudes towards science and its effects on achievement.

Facing the growing need to clarify affective and cognitive relationships among science learners in moredeveloped countries, an instrument was developed to examine both student affects and conceptual understanding simultaneously and their causal relationships (Kim \& Ogawa, 2007). The instrument consists of Likert-scale items on student's attitudes and interests as well as questions to measure student's physics misconceptions. Their affective and cognitive instrument then enabled Kim and Song (2009) to validate the AS-TI-CU model fitted as admissible by confirmatory structural equation modelling (SEM). Sampling $10^{\text {th }}$-graders from a secondary school in Japan, this model disclosed that intrinsic attitude towards science (AS) (career preference, emotional states towards science and favourableness towards school science) has positive causal influence on learners' topic interest (TI) and conceptual understanding (CU) in physics. In contrast to the common belief, however, student perception of the importance of science for society (extrinsic AS) did not have statistically significant influence on TI or CU. Such empirical studies so far in science education have noted the long-disputed hypothesis that the three affective and cognitive factors may stimulate student's school achievement (SA), when examined by a confirmatory SEM. By fitting the new SEM with a Korean sample, the aim of this study is to clarify causal relationships of school achievement (SA) over interest (TI), attitudes towards science (AS), and conceptual understanding $(\mathrm{CU})$.

\section{LITERATURE REVIEW}

\section{Models of school achievement}

Many models in education have conceptualised relationships between cognitive and affective variables to interpret student's learning science. Among the vast amount of the literature, this study presents six of the most distinctive models that have contributed to our rationale. Table 1 summarises endogenous/exogenous variables and conclusions from each model that falls into the three categories: theoretical models, exploratory SEM (structural equation models), and confirmatory SEM.

In the early attempts of modelling how students achieve in school, two theoretical models were derived based on qualitative discussion. First, Rohwer (1984) presented a preliminary model of achievement and its influential variables; they were course and task characteristics, student characteristics (educational values, test anxiety, self-growth, and intrinsic motivation), and study activities (cognitive procedure such as note-taking, outlining, tabulating, working problems, and writing answers; and affective procedure such as anxiety reduction, goal setting, selfreinforcement, and self-talk). In his model, student characteristics account for series of study activities that consequently promote achievement level. This model could be seen as the basis of the following models of school achievement, because it first included both the affective and cognitive variables. Another theoretical explanation of school achievement was introduced by Biggs' (1978) general model of study. Despite its chronological order that precedes the former, Biggs' model is regarded as an enhancement, in that it specifies learners' affective variables into values (attitudes towards science) and motives of learning (topic interest). In addition, Biggs' model attempts to specify student's acts of studying as a series of processes in a 
Table 1. Models of school achievement

\begin{tabular}{|c|c|c|}
\hline Model & $\begin{array}{l}\text { Exogenous / Endogenous } \\
\text { Variables }\end{array}$ & Conclusions \\
\hline \multicolumn{3}{|l|}{ Theoretical models } \\
\hline $\begin{array}{l}\text { Theoretic model of } \\
\text { achievement } \\
\text { (Rohwer, 1984) }\end{array}$ & $\begin{array}{l}\text { Exogenous: course and task } \\
\text { characteristics } \\
\text { Endogenous: student characteristics, } \\
\text { study activities, and achievement level }\end{array}$ & $\begin{array}{l}\text { The exogenous variables consequently influenced } \\
\text { one another. The influence of study activities } \\
\text { finally reached the achievement level in the end. }\end{array}$ \\
\hline $\begin{array}{l}\text { General model of study } \\
\text { processes (Biggs, 1978) }\end{array}$ & $\begin{array}{l}\text { Exogenous: values } \\
\text { Endogenous: motives, strategies, and } \\
\text { academic performance }\end{array}$ & $\begin{array}{l}\text { The exogenous variables influenced one another in } \\
\text { order. The influence of strategies finally reached } \\
\text { the academic performance. }\end{array}$ \\
\hline \multicolumn{3}{|l|}{ Exploratory SEM } \\
\hline $\begin{array}{l}\text { Effects of affective and } \\
\text { cognitive on } \\
\text { achievement } \\
\text { (Lee, 1997) }\end{array}$ & $\begin{array}{l}\text { Exogenous: scientific thinking ability } \\
\text { Endogenous: science inquiry skill, } \\
\text { attitudes towards science, scientific } \\
\text { attitude, and science achievement }\end{array}$ & $\begin{array}{l}\text { Every exogenous influenced science inquiry skill, } \\
\text { attitudes towards science, and scientific attitudes in } \\
\text { order, reaching the science achievement. The final } \\
\text { endogenous variable was estimated at } 54 \% \text {. Science } \\
\text { inquiry skill estimated science achievement by } 0.73 \\
\left(\mathrm{~N}=516 ; 10^{\text {th }} \text {-graders in Korea). }\right.\end{array}$ \\
\hline $\begin{array}{l}\text { Within school model for } \\
\text { achievement } \\
\text { (Kaplan \& Elliott, 1997) }\end{array}$ & $\begin{array}{l}\text { Exogenous: } 5 \text { school variables, e.g., } \\
\text { time in minutes per week for science } \\
\text { Endogenous: } 4 \text { teacher variables, e.g., } \\
\text { degree of emphasis on experiments, } \\
5 \text { student variables, e.g., challenges in } \\
\text { class and grade, and school } \\
\text { achievement }\end{array}$ & $\begin{array}{l}\text { The school variables originate, and correlated one } \\
\text { other. The teacher variables followed them } \\
\text { bridging to the student variables. How often a } \\
\text { student is asked to show her/his understanding in } \\
\text { class influenced school achievement by } 0.18 \text { (N = } \\
1165 ; 10^{\text {th }} \text {-graders in USA). }\end{array}$ \\
\hline \multicolumn{3}{|l|}{ Confirmatory SEM } \\
\hline $\begin{array}{l}\text { Non-science majors' } \\
\text { model of motivation } \\
\text { and achievement } \\
\text { (Glynn, Taasoobshirazi, } \\
\text { \& Brickman, 2007) }\end{array}$ & $\begin{array}{l}\text { Exogenous: gender } \\
\text { Endogenous: belief in the relevance of } \\
\text { science to one's career, motivation, } \\
\text { and school achievement (GPA) in } \\
\text { science }\end{array}$ & $\begin{array}{l}\text { The gender variable weakly influenced the belief, } \\
\text { but the latter robustly estimated the motivation. In } \\
\text { final, the motivation estimated GPA by } 0.63(\mathrm{~N}= \\
\text { 369; undergraduate students in USA). }\end{array}$ \\
\hline $\begin{array}{l}\text { AS-TI-CU model } \\
(\text { Kim \& Song, 2009) }\end{array}$ & $\begin{array}{l}\text { Exogenous: intrinsic/extrinsic attitudes } \\
\text { towards science (AS) } \\
\text { Endogenous: interest (TI) and } \\
\text { conceptual understanding of physics } \\
(\mathrm{CU})\end{array}$ & $\begin{array}{l}\text { Intrinsic AS exclusively estimated the } 11^{\text {th}_{\text {}} \text {-graders' }} \\
\text { conceptual understanding of physics by } 0.61 \text {. } \\
\text { Extrinsic attitudes towards science did not } \\
\text { contribute to any of the endogenous variables with } \\
\text { statistical significance }\left(\mathrm{N}=116 ; 10^{\text {th }} \text {-graders in }\right. \\
\text { Japan). }\end{array}$ \\
\hline
\end{tabular}

unidirectional relationship: values $\rightarrow$ motives $\rightarrow$ strategies $\rightarrow$ academic performance.

Since the 1990s the emergence of structural equation modelling has enabled many researchers to validate their theoretical models fitted by sampled students. Their early work tried to implant numerous factors into a model and explored the most robust factors among them. For example, Lee's (1997) structural equation model presented the effects of affective and cognitive variables on science achievement. Focusing on the content of school science, the model employed learners' scientific thinking ability and science inquiry skills as well as conventional affective and cognitive variables. The findings concluded that science inquiry skills were critical for promoting science achievement (standardised regression coefficient $=0.73$ ). Science achievement, the endogenous variable, was explained (squared correlation $=0.54$ by the model for the $10^{\text {th }}$ graders. Kaplan and Elliott (1997) suggested another achievement-specific model. They presumed that the 13 within-school variables affected school achievement. For exogenous variables of the structural equation model, they employed variables at school level, such as: teacher degree of B.A. in science, minutes per week for science class and laboratory, responses to statements such as "I am happy just to get through the day", the degree of teacher focus on employable skills for students, and degree of teacher goals for student understanding. For endogenous variables at teacher level, the model included the degree of promoting awareness of the use of science in everyday life, the degree of developing science skills, the degree of emphasis on science 
discussion, and the degree of emphasis on experiments. Besides, student-level endogenous variables were considered: student perception of teacher's emphasis on problem-solving skills, how often a student feels challenged in class, and how often a student is asked to show understanding in class. Finally, the model included student's scores of science achievement tests (National Education Longitudinal Study of 1998). This comprehensive model attempted to develop a synthetic structure to contain the school-, teacher-, and studentlevel variables. However, these explanatory models often result in insignificant findings with low regression estimates or low percentage of explanation, in that their aims were set to explore diverse factors for school achievement.

In more-developed countries, students are regarded to possess dichotomous attitudes towards science (Jenkins \& Nelson, 2005; Ogawa, 2006; Ogawa \& Shimode, 2004; Osborne \& Collins, 2001). Based on the characteristic of students, the recent studies designed by confirmatory SEM have focused more on specific aspects of attitudes towards science: favourableness towards careers in science and technology (S\&T) and preference towards school science. How students relate science with themselves in these attitudes turned out to be the most robust to determine their performance. For example, Glynn, Taasoobshirazi, and Brickman (2007) validated a comparable study. In their structural equation model, the motivation questionnaire with five Likert-scales consisted of 30 items such as "I enjoy learning science". Having responded the motivation questionnaire, the sample students were interviewed about their career: "How useful is the science you learn in terms of your career?" The final model fitted with 369 college students indicated that science GPA (school achievement) was influenced mostly by motivation (0.63) and substantially by "belief in the relevance of science to their career" (0.14). The robust regression parameter was reaffirmed by a later model that estimated student's understanding by Kim and Song (2009). By examining the selected factors of attitudes towards science (AS), topic interest (TI or interest inventory II), and conceptual understanding (CU), the model significantly validated the dichotomous structure of attitudes towards science and its impact on $\mathrm{CU}$ (squared correlation $=0.61)$.

\section{Rationale of the new model}

Figure 1 presents the overall rationale of a new model developed in this study. In the latest studies of student attitude, affective variables have been frequently studied in the two perspectives: relevance of science

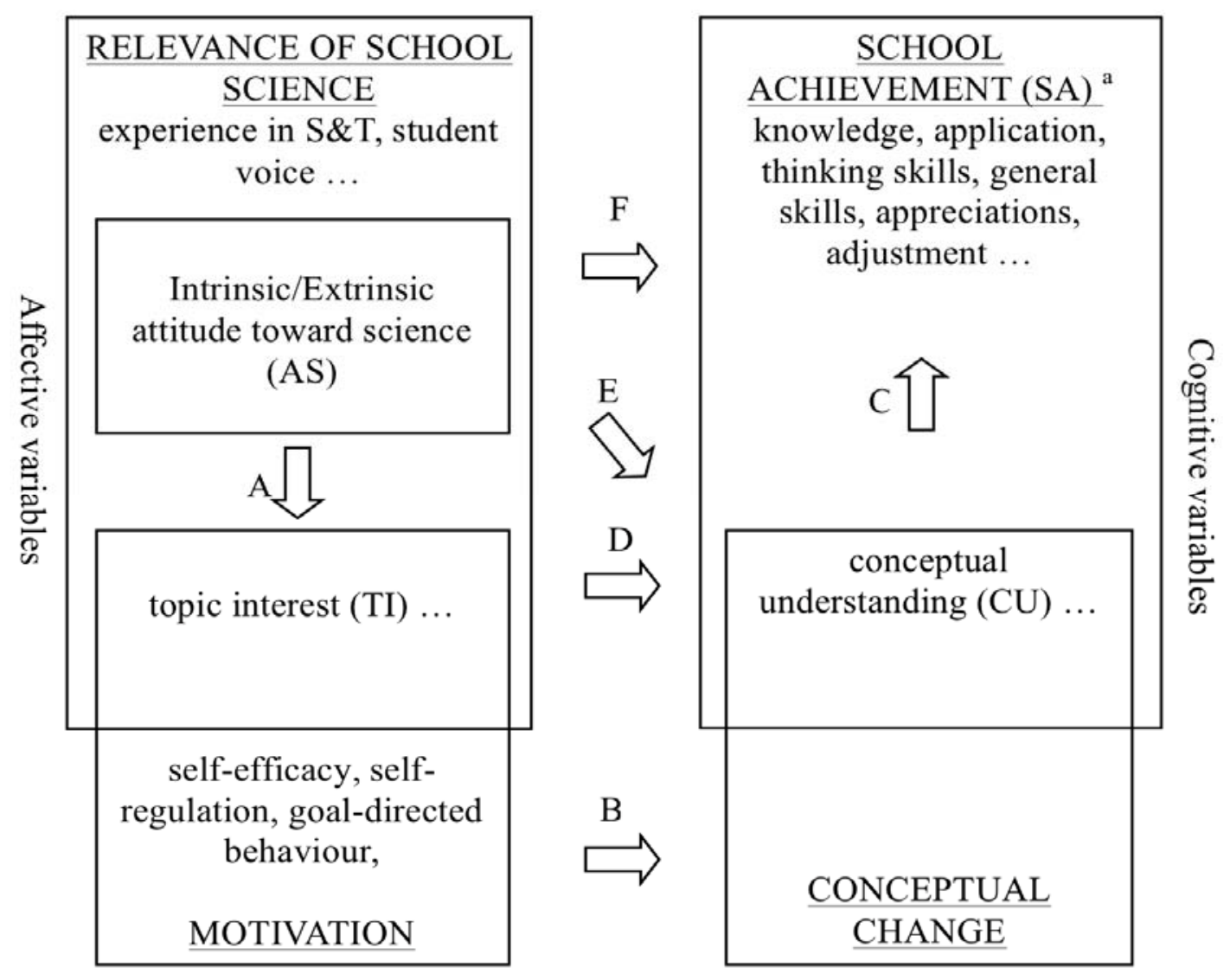

(a $A$ includes interest and attitude as well)

Figure 1. Basic rationale of relationships among AS, TI, CU, and SA 
education (ROSE) and the learning motivation (e.g., Koballa \& Glynn, 2007). The ROSE studies focus on student's attitudes towards science (AS), topic interest (TI), and experience in S\&T, asserting that conventional assessments and their comparative findings over nations have only focused on achievement and thus have a weakness in promoting science education for contemporary students (Schreiner \& Sjøberg, 2004). In the same light, Jenkins and Nelson (2005) employ the perspective of student voice. Their assertion is that students have been marginalised or neglected by educational researchers; students thus should be in the position of making a decision on what to learn in school science (i.e., topic interest), according to how they feel towards school science (i.e., attitudes towards science). These studies note the need to examine the effects of student's attitudes towards science (AS) and topic interest (TI) on cognitive variables among science students.

With regard to cognitive variables in science education, the following studies have clarified how these variables are stimulated by affective variables. For example, student's persistent misconceptions have been examined in order to understand how conceptual changes are influenced by motivational beliefs (Pintrich, Marx, \& Boyle, 1993). Student's consistent conceptual changes are consequently seen to develop conceptual understanding (CU). From its early definition, which refers to student's understanding of science concepts (Edwards \& Fraser, 1983), CU has come to indicate conceptual thinking, which is opposite to the process of problem solving by computational method (Niaz, 1994; Stamovlasis, Tsaparlis, Kamilatos, Papaoikonomou, \& Zarotiadou, 2005). A later definition by Nieswandt (2007) considers CU as a learning process that requires "seeking connections among various pieces of information, or applying the newly learned information to everyday life phenomena" (p. 909). For a clearer understanding of the rationale of causal relationships among AS, TI, CU, and SA, the six pairs of relationships (A-F) are derived from the literature (see Table 2).

The relationship A-F has been assumed to be unidirectional. That is, most of the influential directions are converged towards an assumption that affective variables (AS and TI) influence cognitive variables (CU or SA). This coincides with the research perspective of this study where attitudes and interest are set to estimate learners' conceptual understanding. That is, the affective variable is activated in advance, and the cognitive variable consequently follows. Others may presume a reverse causal relationship that indicates attitudes are enacted by the influence of cognitive variables. However, the cause of AS was examined as consequences of student's various experiences related to school science such as science experiments, science activities of clubs or fairs, library or museum usages, and home resources, excluding school achievement (George \& Kaplan, 1998). Anther piece of empirical evidence on the unidirectional relationship is derived from a nationwide survey that targeted 1.7 million elementary to secondary school students by the Korea Science Foundation (KSF). The Korean students responded that they liked science or mathematics in school more owing to contents that interested them (45.7\%-83.0\%) and less to their school achievement in science subjects $(2.3 \%$ $8.8 \%$ ) (KSF, 2003). These consistent findings support the focus of this study on the unidirectional causal relationship (relationship F; AS $\rightarrow \mathrm{SA}$ ).

\section{RESEARCH QUESTION}

Despite the precedent models in the literature, there still exists a gap of integrating school achievement into the AS-TI-CU model. This integration would provide broader information on how the affective and cognitive

Table 2. Relationships among selected affective and cognitive variables

\begin{tabular}{|c|c|c|}
\hline Relation & Causal direction & Description from the literature \\
\hline A & $\mathrm{AS} \rightarrow \mathrm{TI}$ & $\begin{array}{l}\text { In his structural equation model, Trumper (2006) concluded that the most influential } \\
\text { variable on students' interest in physics was examined by the items of Intrinsic AS } \\
\text { towards science classes. Thus, the direction is set from AS to TI. }\end{array}$ \\
\hline B & $\begin{array}{l}\text { Motivation } \rightarrow \\
\text { Conceptual } \\
\text { change }\end{array}$ & $\begin{array}{l}\text { Pintrich, Marx, and Boyle (1993) indicated motivational constructs (e.g., interest, goal } \\
\text { orientation, values, efficacy beliefs, and control beliefs) could serve as mediators of } \\
\text { conceptual change. }\end{array}$ \\
\hline $\mathrm{C}$ & $\mathrm{CU} \rightarrow \mathrm{SA}$ & $\begin{array}{l}\text { CU was regarded as one of the components of SA (Gronlund, 1971). Thus, their } \\
\text { relationship is set to be single-directional from CU to SA. }\end{array}$ \\
\hline $\bar{D}, \mathrm{E}$ & $\begin{array}{l}\mathrm{TI} \rightarrow \mathrm{CU} \\
\mathrm{AS} \rightarrow \mathrm{CU}\end{array}$ & $\begin{array}{l}\text { In her structural equation model, Nieswandt (2007) concluded that TI and AS influence } \\
\text { students' degree of CU. }\end{array}$ \\
\hline$\overline{\mathrm{F}}$ & $\mathrm{AS} \rightarrow \mathrm{SA}$ & $\begin{array}{l}\text { Willson (1983) meta-analysed the correlation of AS and achievement as being } \mathrm{M}=0.16 \\
\text { (SD =0.16) targeting from kindergarten to the sample college students. Its reverse } \\
\text { direction of relationship was found to be less distinct (George \& Kaplan, 1998; KSF, } \\
\text { 2003). }\end{array}$ \\
\hline
\end{tabular}


variables are related, in maintaining the specific focus on the dichotomous AS among students in the more developed nations. Hence, two different groups of samples, $10^{\text {th }}$ - and $11^{\text {th }}$-graders in Korea, were investigated in this study to resolve the following three research questions:

1. What are causal relationships among attitudes towards science (AS), topic interest (TI), and conceptual understanding (CU) among the Korean students?

2. How is school achievement (SA) estimated by the dichotomous attitudes towards science?

3. What are the group differences between $10^{\text {th }}$ and $11^{\text {th }}$-graders?

\section{METHODOLOGY}

\section{Instrument and sample representativeness}

The instrument in this study originated from 165 affective items from the ROSE (Relevance of Science Education) project (Schreiner \& Sjøberg, 2004) and 40 cognitive items of physics misconceptions from the nation-wide project in Korea (Song, Kim, Kim, Kwon, $\& \mathrm{Oh}, 2004)$. In search of the most critical items among science learners, Kim and Ogawa (2007) employed statistical methods such as factor analysis, item total correlation, and reliability analysis, as well as taking into account the curriculum of the secondary students. The selection of these items was then confirmed by structural equation modelling (Kim \& Song, 2009). The successive study concluded that the model could estimate TI and $\mathrm{CU}$ with statistical significance by dividing the AS items into intrinsic and extrinsic. Therefore, the two types of attitudes towards science (AS) by 13 items, topic interest (TI) by 10 items, and conceptual understanding (CU) in physics by 10 items were employed and translated into the Korean language.

The enhancement in this study is that the 13 AS items were re-examined by their factor loading and reduced them into the five observed variables. To decrease the number of distinct parameters to be estimated (increasing DF), this study grouped theoretically relevant items in AS and examined their means. The grouping was validated to satisfy confirmatory factor analysis conducted by AMOS7 (see Figure 2). The revised structure of AS was fitted with the sample students: $N=219 ; \mathrm{CMIN} / \mathrm{DF}=3.35 ; P<$ 0.05 ; NFI $=0.96$; TLI $=0.93$; $\mathrm{CFI}=0.97$; RMSEA $=$ 0.10 . Although the RMSEA does not fall into 0.08 or less for reasonable model fit, the other indices of model fit were admissible. Also, the RMSEA is not higher than 0.10 with which a model should be rejected (Browne \& Cudeck, 1993). The factor loading in the revised AS is enhanced by $0.64-0.88$, since Kim and Song (2009) reported the items loaded lower by $0.52-0.84$. Other than AS, the items in TI and CU were employed from the literature.

10th-graders $(\mathrm{n}=109)$ and 11th-graders $(\mathrm{n}=110)$ from a high school located in Seoul participated in the pencil-and-paper instrument with the abovementioned items. The latent variables of Intrinsic AS, Extrinsic AS, TI, CU, and SA are described in Table 3 with their observed variables, measurements, means $(\mathrm{M})$, and standard deviations (SD).

For the sample representativeness, the characteristics of both grades are discussed with comparable data from the precedent study. Compared to the Kim and Song's (2009) Japanese students, the Korean sample's students in this study possess a similar mean pattern of attitudes and interest: negative intrinsic and positive extrinsic (dichotomous) AS, and neutral TI (see Appendix, Figure 6). This consistency in both samples can also be supported by Martin and colleagues' (2004) understanding that the Asian countries have been measured as being homogeneous in terms of their affective and cognitive aspects in learning science: "Since these are countries [Chinese Taipei, Japan, and Korea] with high average science achievement, it may be that the students follow a demanding science curriculum, one that leads to high achievement but little enthusiasm for the subject matter" (p. 165).

\section{School achievement (SA)}

In addition to the three known factors, another cognitive variable-school achievement-was collected

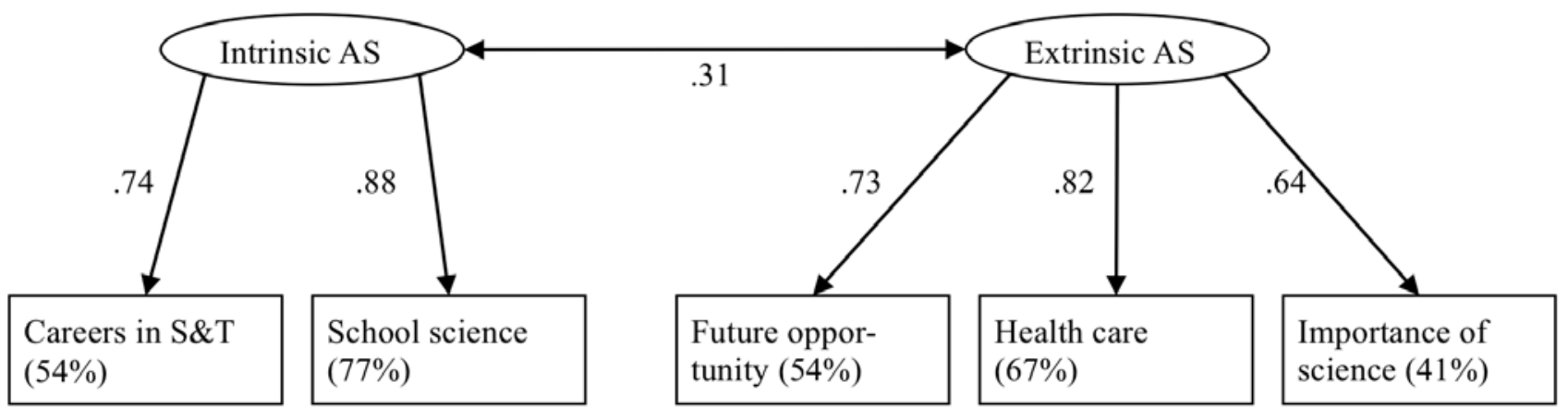

Figure 2. Confirmatory factor analysis of items in attitude toward science (AS); figures in percentages indicate how much variance of each observation is explained. 
from a mid-term examination (see Table 3). By the time they participated into the survey, they had finished the course work of relevant concepts in science. Because the two groups attended different courses (general science for the $10^{\text {th }}$-graders and physics I for the $11^{\text {th }}$ graders), their Z-scores were calculated for the observed variable in the model (see Table 4). The data were employed in two modelling fit processes, regarding the two disparate student groups.

\section{Procedure of structural equation modelling}

Our procedure of structural equation modelling (SEM) followed the task flow of Diamantopoulos and Siguaw (2000): model conceptualisation, path diagram construction, model specification, model identification, parameters estimation, assessment of model fit, model modification, and model cross-validation. In the model conceptualisation and the path diagram construction, the literature was reviewed to construct the basic rationale of causal relationships among AS, TI, CU, and

Table 3. Latent and observed variables (10th-graders, $\mathrm{n}=109$; 11 th-graders, $\mathrm{n}=110$ )

\begin{tabular}{|c|c|c|c|c|}
\hline \multirow{2}{*}{$\begin{array}{c}\text { Latent } \\
\text { variable }\end{array}$} & \multirow{2}{*}{$\begin{array}{l}\text { Observed } \\
\text { variables }\end{array}$} & \multirow{2}{*}{ Measurements } & \multicolumn{2}{|c|}{ M (SD) } \\
\hline & & & $10^{\text {th }}$ & $11^{\text {th }}$ \\
\hline \multirow{3}{*}{$\begin{array}{l}\text { Intrinsic } \\
\text { AS a }\end{array}$} & Careers in & Agreement on items: I would like to get a job in technology; I would like to & 2.21 & 2.34 \\
\hline & $\underline{S E T}$ & become a scientist; School science has opened my eyes to new and exciting jobs & $(0.86)$ & $(0.73)$ \\
\hline & $\begin{array}{l}\text { School } \\
\text { science }\end{array}$ & $\begin{array}{l}\text { Agreement on items: I like school science better than most other subjects; } \\
\text { School science has increased my curiosity about things we cannot yet explain; } \\
\text { School science is rather easy for me to learn }\end{array}$ & $\begin{array}{c}2.22 \\
(0.85)\end{array}$ & $\begin{array}{c}2.46 \\
(0.58)\end{array}$ \\
\hline \multirow{3}{*}{$\begin{array}{l}\text { Extrinsic } \\
\text { AS }\end{array}$} & $\begin{array}{l}\text { Future } \\
\text { opportunity }\end{array}$ & $\begin{array}{l}\text { Agreement on a item: Thanks to science and technology, there will be greater } \\
\text { opportunities for future generations }\end{array}$ & $\begin{array}{c}3.28 \\
(0.91)\end{array}$ & $\begin{array}{c}3.41 \\
(0.82) \\
\end{array}$ \\
\hline & Health care & $\begin{array}{l}\text { Agreement on items: Science and technology make our lives healthier, easier } \\
\text { and more comfortable; Science and technology will find cures for diseases such } \\
\text { as HIV/AIDS, cancer, etc. }\end{array}$ & $\begin{array}{l}3.37 \\
(0.79)\end{array}$ & $\begin{array}{c}3.48 \\
(0.58)\end{array}$ \\
\hline & $\begin{array}{l}\text { Importance } \\
\text { of science }\end{array}$ & Agreement on an item: Science and technology are important for society & $\begin{array}{c}3.52 \\
(0.78) \\
\end{array}$ & $\begin{array}{r}3.80 \\
(0.40) \\
\end{array}$ \\
\hline$\overline{\mathrm{TI}} \mathrm{b}$ & TI-physics & $\begin{array}{l}\text { Interest in topics: sunset, rainbow, using energy, new energy, atomic bomb, } \\
\text { musical instruments, light around us, electricity at home, optical instruments, } \\
\text { and nuclear power plant }\end{array}$ & $\begin{array}{c}2.46 \\
(0.68)\end{array}$ & $\begin{array}{c}2.54 \\
(0.49)\end{array}$ \\
\hline$\overline{\mathrm{CU}} \mathrm{c}$ & CU-physics & $\begin{array}{l}\text { Total score from } 10 \text { questions about the following: magnetic field around wire, } \\
\text { circuit with closed switch, gravity for skydiver, a ball out of round hose, } \\
\text { terminology of energy, force in curving shuttle, work in two slopes, cold } \\
\text { horizontal bar, gravity in water, and circuit with open switch }\end{array}$ & $\begin{array}{c}3.74 \\
(1.95)\end{array}$ & $\begin{array}{c}5.15 \\
(1.90)\end{array}$ \\
\hline$\overline{\mathrm{SA}}$ & $\begin{array}{l}\text { Z-score of } \\
\text { school science }\end{array}$ & Mid-term examination by 2 paper tests for each $10^{\text {th }}$ - and $11^{\text {th }}$-grader & $\begin{array}{c}.00 \\
(1.00)\end{array}$ & $\begin{array}{c}.00 \\
(1.00)\end{array}$ \\
\hline
\end{tabular}

${ }^{\mathrm{a}}$ scale: 1. disagree - 4. agree; ${ }^{\mathrm{b}}$ scale: 1 . not interested -4 . interested; ${ }^{\mathrm{c}}$ scores varying $0-10$

Table 4. Raw data and Z-score for school achievement (Korean sample students, $N=219$ )

\begin{tabular}{ccccc}
\hline Grade & \multicolumn{2}{c}{ Raw data } & \multicolumn{2}{c}{ Z-score } \\
\hline $10^{\text {th }}$ & $\mathrm{M}$ & 55.74 & $\mathrm{M}$ & 0.00 \\
$(\mathrm{n}=109)$ & $\mathrm{SD}$ & 21.64 & $\mathrm{SD}$ & 1.00 \\
& Median & 54.00 & Median & -0.08 \\
& Minimum & 11.00 & Minimum & -2.07 \\
& Maximum & 96.00 & Maximum & 1.86 \\
\hline $11^{\text {th }}$ & $\mathrm{M}$ & 26.65 & $\mathrm{M}$ & 0.00 \\
$(\mathrm{n}=110)$ & $\mathrm{SD}$ & 11.29 & $\mathrm{SD}$ & 1.00 \\
& Median & 24.50 & Median & -0.19 \\
& Minimum & 5.00 & Minimum & -1.92 \\
& Maximum & 50.00 & Maximum & 2.07 \\
\hline
\end{tabular}


SA (see Figure 2). In the model specification, error variances of the observed variables TI-physics, CUphysics, and Z-score of school science were calculated as $0.07,1.58$, and 0 according to the precedent model (Kim \& Song, 2009). In the model identification, the number of degrees of freedom was calculated as follows:

1. Number of observed variables per model (q): 8

2. Number of distinct sample moments per model: $q(q+$ 1)/ $2=36$

3. Number of distinct parameters to be estimated per model: 12 weights (regression estimates, unidirectional arrows) + 1 covariance (between Intrinsic and Extrinsic AS) +10 variances (latent or error variables) $=23$

4. Degree of freedom per model: $36-23=13$

5. Degree of freedom for $10^{\text {th }}$ and $11^{\text {th }}$ models (DF): $13 * 2$ $=26$

Since this study conducted multiple-group analysis of SEM, the two models were fitted with each $10^{\text {th }}$ and $11^{\text {th }}$-grader. That is, the DF was doubled $(13 * 2=26)$. The DF higher than zero indicates that the number of observed variables (raw information) is sufficient enough to estimate the unknown parameters. In the parameter estimation, the maximum likelihood method of AMOS7 was employed to estimate the parameters. In the assessment of model fit, the model fit indices such as CMIN/DF, NFI, TLI, CFI, and RMSEA were examined to satisfy each criterion. This study did not carry out the procedure of model modification; given that the model had already enhanced its model fit indices by reconstructing the AS items through the confirmatory factor analysis (see Figure 1). In the model cross-validation, this step was carried out by fitting the two groups (10 $10^{\text {th }}$ and $11^{\text {th }}$-graders) in the single model. If this multiple-group analysis of SEM satisfies the model fitness and produces consistent findings, the AS-TI-CUSA model is cross-validated.

\section{Theoretical model and premises}

This study employed the precedent model of AS, TI, and CU suggested by Kim and Song (2009). In addition, another cognitive factor SA was implanted in AS-TICU-SA (see Figure 3) with the two premises as follows:

Premise 1: Students with higher topic interest (TI) in physics could achieve better in school achievement (SA). According to Schiefele and colleague (1992), students who are interested in learning a topic are apt to engage in studying activities they believe will help them to learn better. Such activities include focusing carefully on the instruction and employing adequate studying strategies for the topic. On the other hand, students who are not interested in learning the topic are apt not to strategically manage their studying activities. The latter students may be inattentive during their lessons and they do not organise or rehearse the material.

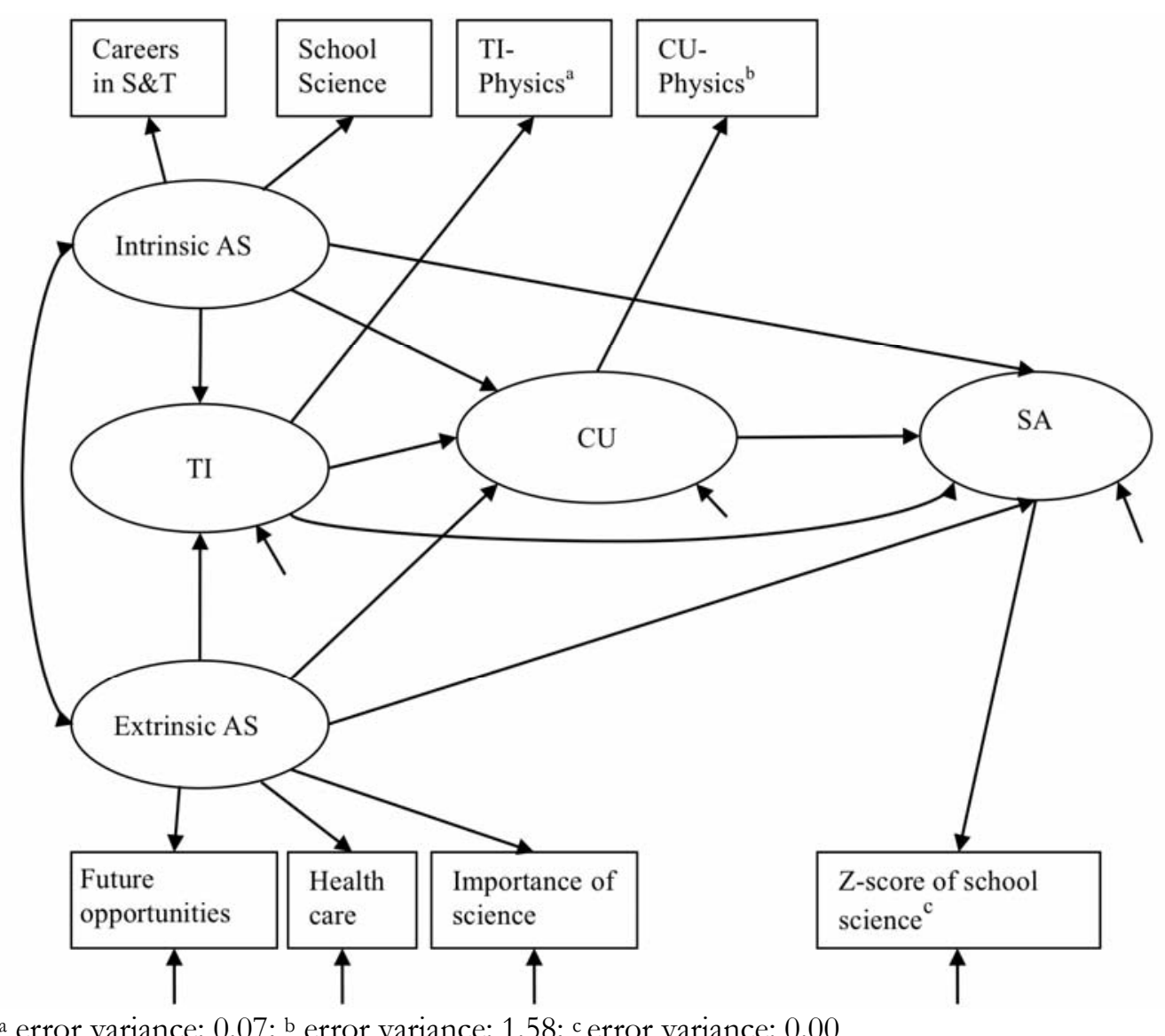

Figure 3. Initial AS-TI-CU-SA model in AMOS7 
Premise 2: Students possessing higher conceptual understanding $(\mathrm{CU})$ of physics may perform better in their school achievement (SA) of physics. Understanding has been referred to as one of the general criteria of assessments including knowledge, understanding, application, thinking skills, general skills, attitudes, interests, appreciations, and adjustment (Linn \& Gronlund, 1993). Because school achievements (SA) are aimed at properly evaluating all the components of the criteria, (conceptual) understanding in a subject is supposed to influence learners' SA. In addition, various concepts situated within the everyday or within fantasy have been considered to be associated with evaluations of problem solving capability in physics (Scott, 1985; Stark, 1999). Therefore, a student with higher CU is expected to solve more concepts derived from various situations in school examinations.

\section{FINDINGS}

\section{AS-TI-CU-SA model}

In the AS-TI-CU-SA model which implanted school achievement (SA) variable in the precedent AS-TI-CU model. The model fitting was calculated as being acceptable, as shown in Table 5. The Chi-Square divided by the degree of freedom is 1.44 , which is reasonable with the probability level of 0.07. Likewise, the other indices such as TLI, CFI, and RMSEA consistently fell within each criterion. Because the Korean sample ( $N=$ 219) was divided into $10^{\text {th }}$-graders $(n=109)$ and $11^{\text {th }}$ graders $(n=110)$ by different examinations of school achievement (SA), each model was depicted respectively (see Figure 4 and Figure 5). In AMOS7 output format, every estimate which has their critical ratio in the condition of $|\mathrm{CR}|>2.0$ are statistically significant in $P$ $=0.05$ level (Han, Omta, \& Trienekens, 2007).

Regardless of the additional latent variable, school achievement (SA), Figure 4 indicates that the AS-TICU-SA model fits with Korean $10^{\text {th }}$-graders and confirms the consistent structure with parameter significance to Kim and Song's (2009) AS-TI-CU model fitted with Japanese $10^{\text {th }}$-graders. These consistent findings include (1) that Intrinsic AS which concerns general science (favourableness towards careers in S\&T)

Table 5. Model fit indices of AMOS solution on ASTI-CU-SA model $(\mathrm{N}=109+110)$

\begin{tabular}{ccc}
\hline Index & Criterion & Model fit \\
\hline CMIN / & $1<<3$ & $37.49 / 26=1.44$ \\
DFa & approaches 1 & 0.93 \\
NFI & approaches 1 & 0.95 \\
TLI & approaches 1 & 0.98 \\
CFI & RMSEA $<0.08$ & 0.04 \\
RMSEA &
\end{tabular}

${ }^{a} C M I N=$ Chi-Square, $D F=$ degree of freedom estimates TI (topic interest in how rainbows occur) and $\mathrm{CU}$ (understanding on magnetic field around wire) in physics; (2) Extrinsic AS (agreement on importance of science) does not contribute to stimulating TI or CU; (3) Even though both variables concern the contents of physics, TI and CU have little causal relationship.

With regard to stimuli of school achievement (SA), $\mathrm{CU}$ was examined to exclusively estimate SA most robustly by 0.48 . Any other latent variables do not possess causal relationships with SA with parameter significance $(P>0.05)$. That is, if students have improved their conceptual understanding in physics from 1 to 100 scores, they would achieve school achievement from 1 to 48. The AS-TI-CU-SA could explain $33 \%$ of the variance in SA, and due to that there exists other variables beyond the scope of this study. What is also notable is that Intrinsic AS estimates little of SA. Due to their sequent directions of causal influence (Intrinsic AS $\rightarrow \mathrm{CU} \rightarrow \mathrm{SA}$ ), indirect effects of Intrinsic AS on SA is seemingly predicted, and discussed later in this section.

Among both $10^{\text {th }}$ and $11^{\text {th }}$-graders, multiple group analysis examined the group difference by comparing critical ratios between each pair of parameters (group significance). As shown in Figure 5, the three identical estimates with parameter significance, but without group significance (i.e., none group difference), were confirmed. Furthermore, the relationship from TI to SA was identified as being negative (-0.31) with both parameter significance $(C R=4.57 ; P<0.001)$ and group significance $(C R=-2.42 ; P=0.05)$. That is, higher topic interest (TI) decreased school achievement (SA) only among the $11^{\text {th }}$-graders.

As assumed in Figure 4, school achievement (SA) was examined to determine whether it has an indirect effect. The first column in Table 6 presents direct effects on SA, which are identical on the estimates depicted on each $10^{\text {th }}$ - and $11^{\text {th }}$-model. In the second column, the indirect effects were also examined from Intrinsic AS ( 0.37 in the $10^{\text {th }} ; 0.20$ in the $\left.11^{\text {th }}\right)$. That is, Intrinsic AS, which was found to be a major predictor of CU and TI, was not measured to influence school achievement $(\mathrm{SA})$ by direct effects $\left(-0.01\right.$ in the $10^{\text {th }}$; insignificant in the $\left.11^{\mathrm{th}}\right)$. Rather, the indirect effect of Intrinsic AS was estimated to be robust among the final model both in $10^{\text {th }}$ - and $11^{\text {th }}$-graders. This causal relationship confirms that Intrinsic AS first stimulates $\mathrm{CU}$ extending its influence to $\mathrm{SA}$ (Intrinsic AS $\rightarrow \mathrm{CU}$ $\rightarrow$ SA).

In summary, the AS-TI-CU-SA model concludes the three empirical findings. First, the SEM analysis of the Korean students $(N=219)$ attested another piece of evidence to the effects of attitudes towards science (AS) on topic interest (TI) and conceptual understanding (CU). The dichotomous AS_-students perceive science to be important but not for their career or school 
Table 6. Standardised direct and indirect effects on school achievement (SA)

\begin{tabular}{ccccc}
\hline Grade & Latent variable & Direct effect & Indirect effect & Total effect \\
\hline $10^{\text {th }}$-graders & Intrinsic AS & -0.01 & 0.37 & 0.37 \\
& Extrinsic AS & 0.05 & 0.04 & 0.09 \\
& Topic interest (TI) & 0.18 & 0.00 & 0.18 \\
& Conceptual understanding (CU) & 0.48 & 0.00 & 0.48 \\
\hline $11^{\text {th }}$-graders & Intrinsic AS & 0.33 & 0.20 & 0.53 \\
& Extrinsic AS & -0.20 & 0.20 & 0.00 \\
& Topic interest (TI) & -0.31 & 0.08 & -0.22 \\
& Conceptual understanding (CU) & 0.79 & 0.00 & 0.79 \\
\hline
\end{tabular}

subject-was prevalent among the sample students in Korea (see Table 3), which is consistent with the precedent reports among Japanese and European students (Jenkins \& R. G. Pell, 2006; Kim \& Song, 2009; Matthews, 2007; Osborne \& Collins, 2001; Stefánsson, 2006). It reassures that student's preference on careers in S\&T and school science (Intrinsic AS) is a strong determinant of how much students understand physics concepts among the Korean samples (see Figure 4 and Figure 5). Second, this reassurance is followed by the discussion on stimuli of school achievement (SA). Intrinsic AS was examined to extend its influence into SA mostly by indirect effects passing through CU (see Table 6). Third, the multiple-group analysis of structural equation modelling identifies the difference between the $10^{\text {th }}$ and $11^{\text {th }}$-graders. Among the $11^{\text {th }}$-graders who generally concentrate more on advancing to higher education than the $10^{\text {th }}$-graders do, the interest in the 10 physics topics in school science moderately hinders them in obtaining higher school achievement in physics.

\section{Limitation}

The size of the sample $(N=219)$ in this study might be arguable in declaring the model representativeness. However, as a trait of a structural equation modelling, it is notable that the model was first derived by theoretical discussion of the affective and cognitive variables in science education (see Figure 1), not solely induced by the empirical analysis. In the light, the sample fitting and the acceptable model fit indices (NFI, TLI, CFI, and RMSEA) enable us to explain the long-studied question of how student attitudes influences school achievement. The aim of this study is not mainly to describe how the Korean students present certain degree of attitude, interest, or understanding, but to validate the new model of achievement constructed by these variables. The following implication will demonstrate what to interpret by the model of achievement among the Korean students.

\section{IMPLICATION}

\section{Latent threats of negative attitude}

Student's unfavourableness towards science has provoked the concern that future society would lack talented human resources in S\&T among the more developed countries (Osborne, Simon, \& Collins, 2003). Policy-makers, scientists, science education researchers, and science teachers have regarded this latent threat as the most imperative, because the era of the sciencetechnology society calls for more scientific knowledge which, in turn, supports national economic development (Jenkins \& Nelson, 2005; Ogawa, 2006). For the extrinsic reason, it has been addressed that student's positive attitudes and interest in science should be instructed, as set in the national curriculum of science education. For instance, the Korean government has kept a keen interest in student's attitudes towards science and scientific literacy. Although far above the average score of participant countries in PISA, the Organization for Economic Co-operation and Development (OECD) reports that Korean student's enjoyment and motivation of learning science have been examined as being negative and lower than average (OECD, 2007). Regarding these affective factors as stimuli of student's achievement for the future society, the recent national report by the Korea Institute of Curriculum \& Evaluation (KICE) claims that student's negative attitudes and interest are attributable to the slight, gradual decrease in their scientific literacy over PISA 2000, 2003, and 2006 (KICE, 2007). In keeping with the precedent model, the AS-TI-CU-SA model fitted in this study confirmed student's attitudes towards science concerning a career or a school subject contributes to learners' conceptual understanding and, in consequences, to their school achievement of science. In summary, negative attitudes towards science raise two threats for the future society: they decrease number of applicants to careers in S\&T, and they discourage students to become talented in school science. 


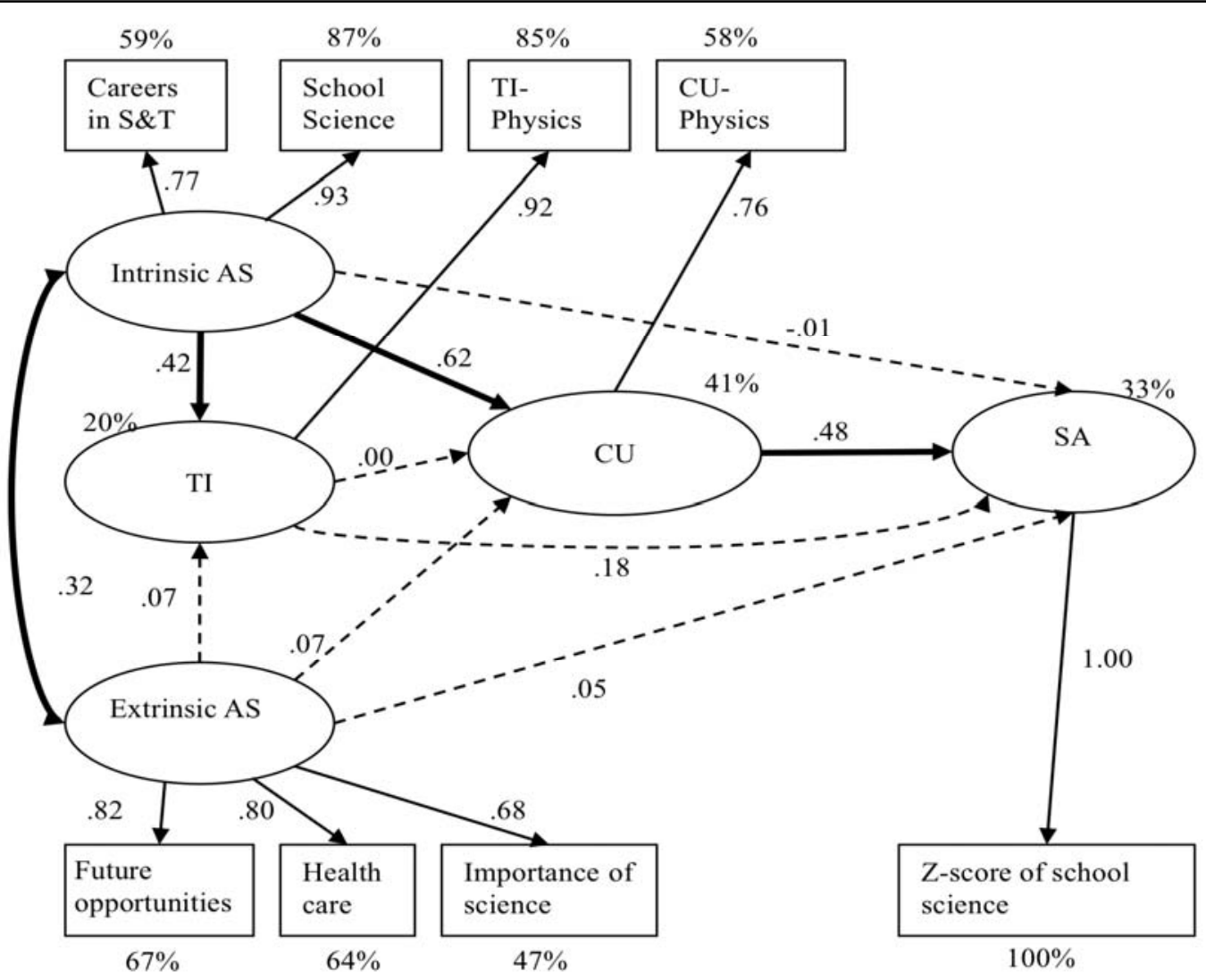

Figure 4. AS-TI-CU-SA model in 10th-graders $(n=109)$ with standardised estimates; the percentages indicate how much variance of each observation is explained; significant estimates are highlighted in bold.

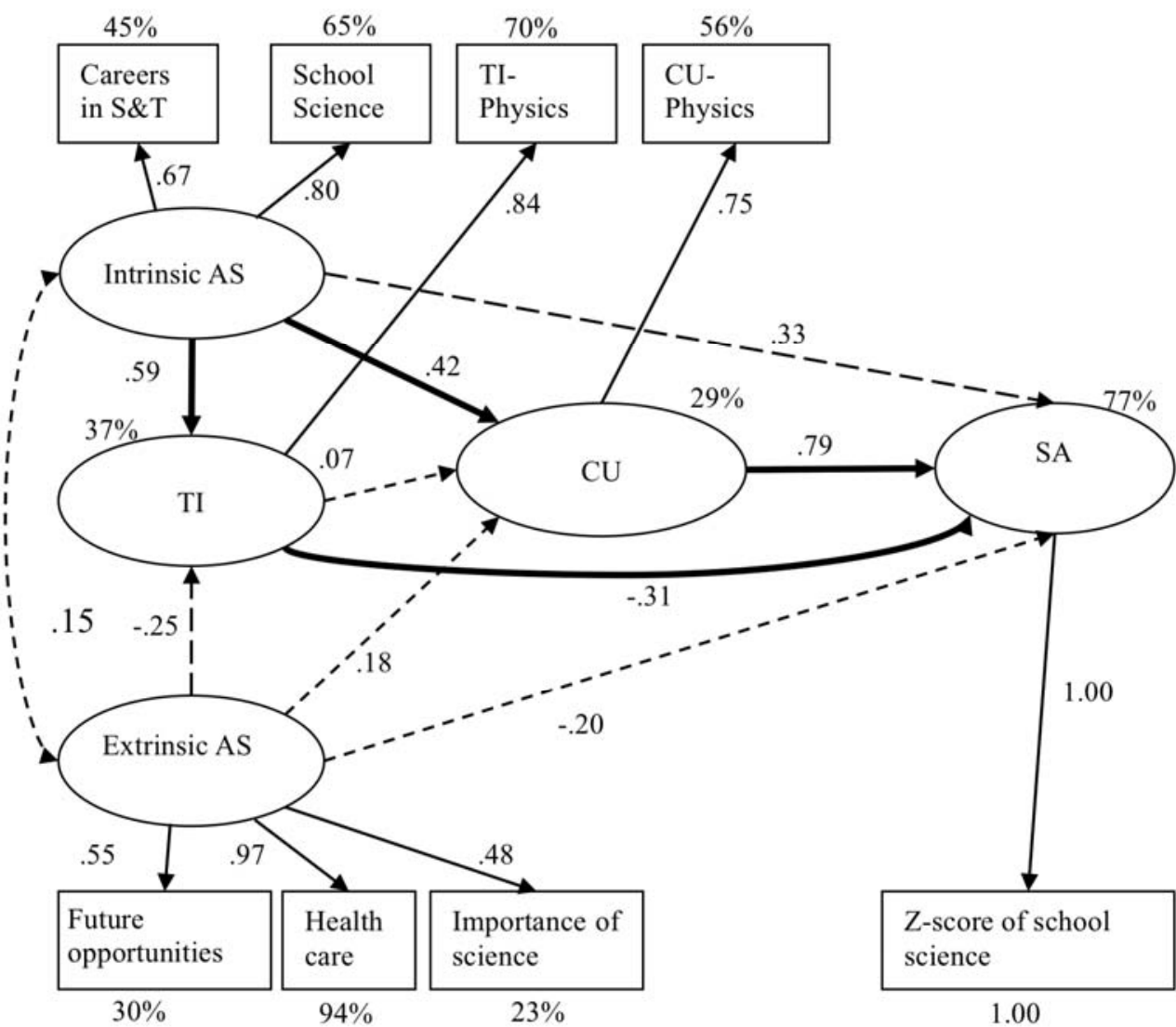

Figure 5. AS-TI-CU-SA model in 11th-graders $(n=110)$ with standardised estimates; figures in percentage indicate how much variance of each observation is explained; significant estimates are highlighted in bold. 


\section{Grounds of the "age 14's dip"}

The sampled $11^{\text {th }}$-graders were examined to possess a negative estimate coefficient of interest on school achievement: those who highly wish to learn the everyday phenomenon, sunset, rainbow, using energy, and new energy, may not succeed in their physics test. According to the study by Bennett and Hogarth (2009), the "age 14's dip" could account for this abnormal finding, as 14-year-old students are matched into the Korean $11^{\text {th }}$-graders. The specific cohorts are examined to temporarily alter their attitudes towards careers in S\&T as more negative and unstable. Within the curriculum where $11^{\text {th }}$-graders encounter the specialised subjects such as physics, biology, chemistry, and earth science, the unfamiliar difficulty of these subjects may cause such a contradictory causal relationship. Despite the limited size of the sampling, it is possible to infer that the instruction for the $11^{\text {th }}$-graders ignored what they were interested to learn about during school physics. In the light, Aikenhead (2006) claimed what the students want to know (personal-curiosity science) has not been in accord with what they are told to learn (wish-they-know science). Questioning "Who decides what is relevant?" he argued that those who design science curriculum-scientists, education officials, and science teachers-make the decisions of what to learn in science lessons; but, the wish-they-know science is not always as effectively taught as it should be for university science. Likewise, it stands to reason that the relevant science for the $11^{\text {th }}$-graders conflicted with what they were instructed to learn from the advanced physics, presenting the negative regression coefficient in our SEM.

\section{Further research questions}

In what channel have we persuaded students of the advantages of careers in S\&T? Is the persuasion educationally and morally acceptable? The present study and the precedent literature by Kim and Song (2009) have consistently shown why a positive attitudes towards science-favourableness towards careers in S\&T-matters and how much the current school science fails in satisfying student's interest in science education. In terms of changing student's attitudes, the early theoretical study by Koballa (1992) illustrated how to persuade students in the $21^{\text {st }}$ century. He cautioned science teachers against using any of the educationally improper channels to change student's attitudes: propaganda ("communication techniques to spread doctrines"), coercion ("reinforcement control to induce behaviour"), indoctrination ("biased presentation of a debatable issue"), and brainwashing ("an irresistible method of achieving total control over the human mind") (pp. 6771). He argued that persuasion should be carried out by using the proper educational channel of instruction ('formation of beliefs that are held "evidentially") that helps students to decide which attitudes is reasonable for them, while freed from any external reinforcement or biases (p. 72). When formal science education is arranged in a restricted manner with a textbook and school experiments by a science teacher, students may not be provided with the abundant or balanced information so as to garner a positive attitudes towards elective science courses or careers in S\&T. Therefore, examining which channel has been used to persuade students will be a prerequisite for knowing how to change their attitudes.

What theories can be set for the persuasion of attitude? In what context are the theories valid? A few local studies have detected successful persuasion towards careers in S\&T in the informal science education such as interdisciplinary education and out-of-school science. For example, Hasse (2005) found that Italian female students made up almost twice the number of physicists $(45 \%)$ at university than their Danish counterparts did (18-20\%), owing to the interdisciplinary approach-the classical language courses where female students developed skills of thinking in abstractions and making inferences. In early out-of-school science, inviting a woman scientist into the classroom was found to be effective helping both girls and boys to construct sound role models for careers in S\&T (Smith \& Erb, 1986). Later, in more active out-of-school science, students visited science centres, which helped them to form positive attitudes (Jarvis \& A. Pell, 2005; Ricks, 2006). Nevertheless, there is much yet to understand, given that these findings are temporal and inconsistent: a study carried out in the four European research centres still reports difficulty in finding significant effects of persuasion (Neresini, Dimopoulos, Kallfass, \& Peters, 2009). By accumulating the local case studies, future attempts at such informal science education will enable us to theorise persuasion of attitude change that applies to a broader context.

\section{REFERENCE}

Aikenhead, G. S. (2006). Science education for everyday life Evidence-based practice. New York: Teachers College Press.

Baker, R., \& Jones, A. (2005). How can international studies such as the international mathematics and science study and the programme for international student assessment be used to inform practice, policy and future research in science education in New Zealand. International Journal of Science Education, 27(2), 145-157.

Barmby, P., Kind, P. M., \& Jones, K. (2008). Examining changing attitudes in secondary school science. International Journal of Science Education, 30(8), 1075-1093.

Bennett, J., \& Hogarth, S. (2009). Would you want to talk to a scientist at a party? High school students' attitudes to school science and to science. International Journal of Science Education, 31(14), 1975-1998. 
Biggs, J. B. (1978). Individual and group differences in study processes. British Journal of Educational Psychology, 48(3), 266-79.

Browne, M. W., \& Cudeck, R. (1993). Alternative ways of assessing model fit. (K. A. Bollen \& J. S. Long, Eds.). London: Sage.

Diamantopoulos, A., \& Siguaw, J. A. (2000). Introducing LISREL: A guide for the uninitiated. (D. B. Wright, Ed.). London: Sage Publications Ltd.

Edwards, J., \& Fraser, K. (1983). Concept maps as reflectors of conceptual understanding. Research in Science Education, 13(1), 19-26.

George, R., \& Kaplan, D. (1998). A structural model of parent and teacher influences on science attitudes of eighth graders: Evidence from NELS: 88. Science Education, 82(1), 93-109.

Glynn, S. M., Taasoobshirazi, G., \& Brickman, P. (2007). Nonscience majors learning science: A theoretical model of motivation. Journal of Research in Science Teaching, 44(8), 1088-1107.

Han, J., Omta, S. W. F., \& Trienekens, J. H. (2007). The joint impact of supply chain integration and quality management on the performance of pork processing firms in China. International Food and Agribusiness Management Review, 10(2).

Hasse, C. (2005). Cultural models of gender in science: Women in physics through the cultural-psychological magnifying glass. In P. Valero \& O. Skovsmose (Eds.), University science and mathematics education - Challenges and possibilities (pp. 1-20). København: DCN Press. Retrieved May 20, 2009, from http://www.dpu.dk/everest/showdoc.asp?id=0611201 12844\&type $=$ doc.

Head, J. (1985). The personal response to science. London: Cambridge University Press Cambridge.

Jarvis, T., \& Pell, A. (2005). Factors influencing elementary school children's attitudes toward science before, during, and after a visit to the UK National Space Centre. Journal of Research in Science Teaching, 42(1), 53-83.

Jenkins, E. W., \& Nelson, N. W. (2005). Important but not for me: students' attitudes towards secondary school science in England. Research in Science \& Technological Education, 23(1), 41-57.

Jenkins, E. W., \& Pell, R. G. (2006). The relevance of science education project (ROSE) in England: A summary of findings. Leeds: Centre for Studies in Science and Mathematics Education, University of Leeds.

Kaplan, D., \& Elliott, P. R. (1997). A model-based approach to validating education indicators using multilevel structural equation modeling. Journal of Educational and Behavioral Statistics, 22(3), 323-347.

KICE. (2007). The results from PISA 2006. Seoul: Korea Institute of Curriculum \& Evaluation.

Kim, M., Lavonen, J., \& Ogawa, M. (2009). Experts' opinion on the high achievement of scientific literacy in PISA 2003: A comparative study in Finland and Korea. Eurasia Journal of Mathematics, Science \& Technology Education, 5(4), 379-393.

Kim, M., \& Ogawa, M. (2007). Development of an instrument for measuring affective factors regarding conceptual understanding in high school physics. Journal of the Korean Association for Research in Science Education, 27(6), 497-509.

Kim, M., \& Song, J. (2009). The effects of dichotomous attitudes toward science on interest and conceptual understanding in physics. International Journal of Science Education, 99999(1), 1-22.

Koballa, T. R. (1992). Persuasion and attitude change in science education. Journal of Research in Science Teaching, 29(1), 63-80.

Koballa, T. R., \& Glynn, S. M. (2007). Attitudinal and motivational constructs in science learning. In S. K. Abell \& N. G. Lederman (Eds.), Handbook of Research on Science Education (pp. 75-102). London: Lawrence Erlbaum Associates, Publishers.

KSF. (2003). Study of the national survey on the students' recognition toward science \&o technology. Korea Science Foundation.

Lee, K. (1997). Construction of a structural equation model on attitudes to science using LISREL. Journal of the Korean Association for Research in Science Education, 17(3), 301-311.

Linn, R. L., \& Gronlund, N. E. (1993). Measurement and evaluation in teaching $\left(10^{\text {th }}\right.$ ed.). New Jersey: The Macmillan Company.

Martin, M. O., Mullis, I. V. S., Gonzalez, E. J., \& Chrostowski, S. J. (2004). TIMSS 2003 international science report. Chestnut Hill, United States: TIMSS \& PIRLS International Study Center.

Matthews, P. (2007). The relevance of science education in Ireland. Dublin: Royal Irish Academy.

Neresini, F., Dimopoulos, K., Kallfass, M., \& Peters, H. P. (2009). Exploring a black box: Cross-national study of visit effects on visitors to large physics research centers in Europe. Science Communication, 30(4), 506-533.

Niaz, M. (1994). Progressive transitions from algorithmic to conceptual understanding in student ability to solve chemistry problems: A Lakatosian interpretation.

Nieswandt, M. (2005). Attitudes toward science: A review of the field. In S. Alsop (Ed.), Beyond Cartesian Dualism Encountering Affect in the Teaching and Learning of Science (Vol. 29, pp. 41-52). Dordrecht: Springer.

Nieswandt, M. (2007). Student affect and conceptual understanding in learning chemistry. Journal of Research in Science Teaching, 44(7), 908-937.

OECD. (2007). PISA 2006 science competencies for tomorrow's world: Volume 1. Paris, France: Organisation for economic co-operation and development (OECD).

Ogawa, M. (2006). Even science lovers do not want to become scientists or engineers: From ROSE data in Japan. CONNECT (UNESCO), 31, 5-9.

Ogawa, M., \& Shimode, S. (2004). Three distinctive groups among Japanese students in terms of their school science preference: From preliminary analysis of Japanese data of an international survey 'the Relevance of Science Education' (ROSE). Journal of Science Education in Japan, 28(4), 279-291.

Osborne, J., \& Collins, S. (2001). Pupils' views of the role and value of the science curriculum: A focus-group study. International Journal of Science Education, 23(5), 441 - 467.

Osborne, J., Simon, S., \& Collins, S. (2003). Attitudes towards science: A review of the literature and its implications. International Journal of Science Education, 25(9), 1049-1079. 
Pintrich, P. R., Marx, R. W., \& Boyle, R. A. (1993). Beyond cold conceptual change: The role of motivational beliefs and classroom contextual factors in the process of conceptual change. Review of Educational Research, 63(2).

Ricks, M. (2006). A study of the impact of an informal science education program on middle school students' science knowledge, science attitude, STEM high school and college course selections, and career decisions. The University of Texas at Austin.

Rohwer, W. D. (1984). An invitation to an educational psychology of studying. Educational Psychologist, 19(1), 114.

Schibeci, R. A. (1984). Attitudes to science: an update. Studies in Science Education, 11, 26-59.

Schiefele, U., Krapp, A., \& Winteler, A. (1992). Interest as a predictor of academic achievement: A meta-analysis of research. In K. A. Renninger, S. Hidi, \& A. Krapp (Eds.), The role of interest in learning and development (pp. 183-212). Hillsdale, New Jersey: Lawrence Erlbauy Associates, Publishers.

Schreiner, C., \& Sjøberg, S. (2004). Sowing the seeds of ROSE. Background, rationale, questionnaire development and data collection for ROSE (The relevance of science education) - $A$ comparative study of students' views of science and science education. Oslo: Dept. of Teacher Education and School Development, University of Oslo.

Scott, B. L. (1985). A defense of multiple choice tests. American Journal of Physics, 53(11), 1035.

Smith, W. S., \& Erb, T. O. (1986). Effect of women science career role models on early adolescents' attitudes toward scientists and women in science. Journal of Research in Science Teaching, 23(8), 667-676.

Song, J., Kim, I. G., Kim, Y. M., Kwon, S., \& Oh, W. K. (2004). Map of students' physics misconceptions. Seoul: Book's-hill.

Stamovlasis, D., Tsaparlis, G., Kamilatos, C., Papaoikonomou, D., \& Zarotiadou, E. (2005). Conceptual understanding versus algorithmic problem solving: Further evidence from a national chemistry examination. Chemistry Education Research and Practice, 6(2), 104-118.

Stark, R. (1999). Measuring science standards in Scottish schools: The assessment of achievement programme. Assessment in Education: Principles, Policy \& Practice, 6(1), $27-41$.

Stefánsson, K. K. (2006). 'I just don't think it's me': A study on the willingness of Icelandic learners to engage in science related issues. Faculty of Education, University of Oslo.

Tsai, C., \& Kuo, P. (2008). Cram school students' conceptions of learning and learning science in Taiwan. International Journal of Science Education, 30(3), 353-375.

Ziman, J. (1968). Public knowledge: The social dimension of science. Cambridge University Press. 


\section{APPENDIX}

\section{Sample representativeness}

Figure 6 indicates that Korean $10^{\text {th }}$ and $11^{\text {th }}$-graders have similar means of Intrinsic AS, Extrinsic AS, and Topic Interest to the Japanese $10^{\text {th }}$-graders from Kim and Song's (2009) Japanese sample. The observed variables in the Intrinsic AS are measured as being near 2.50 or less (negative), while those in the Extrinsic AS are 3.35 or higher (positive), which are referred to as dichotomous attitudes towards science in the literature. In addition, The Topic Interest in physics is neutral (2.50) both in the Korean and Japanese sample students.

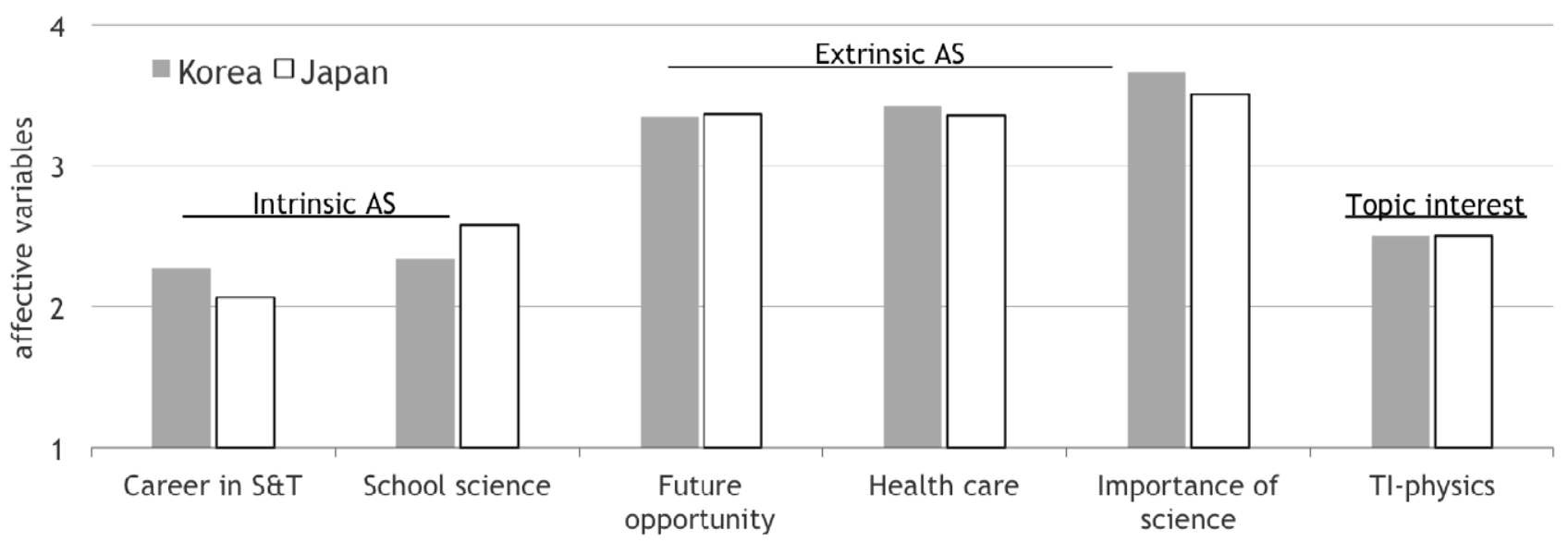

4-choice Likert scale: 1. disagree (not interested) - 4.agree (very interested)

Figure 6. Similarity in mean of affective variables among the Korean students in this study $(\mathbf{N}=219)$ paralleled with the Japanese data $(\mathrm{N}=114)$ by Kim and Song (2009) 